\title{
The Use of Integrated Teaching Materials of Earth and Space Sciences (ESS) which Accommodate Multiple Intelligences to Increase Students' Mastery Concept of Junior High School
}

\author{
Winny Liliawati, \\ Department of Physics Education \\ Indonesia University of Education \\ Bandung, Indonesia \\ winny.liliawati@gmail.com
}

\author{
Judhistira Aria Utama \\ Department of Physics Education \\ Indonesia University of Education \\ Bandung, Indonesia \\ j.aria.utama@upi.edu
}

\author{
Taufik Ramlan Ramalis \\ Department of Physics Education \\ Indonesia University of Education \\ Bandung, Indonesia \\ taufik_lab.ipba@upi.edu
}

\author{
Lisda Sa'adillah Mursyidah \\ Department of Physics Education \\ Indonesia University of Education \\ Bandung, Indonesia \\ lisdasopyan@gmail.com
}

\begin{abstract}
This research aims to increase students' mastery concepts in the material motion of celestial bodies using integrated ESS (Earth and Space Sciences) teaching materials which accommodate multiple intelligences. Preliminary identification of the 32 students of ninth class in one of Junior High School showed that intellectuals are diverse. It was found that the dominant intelligence of the students is kinesthetic intelligence, while the lowest one is a logical mathematical intelligence. Using an appropriate teaching material which accomodate those multiple intelligences may enhance students' mastery concepts. The appearance of students multiple intellectual was observed by multiple intelligence questioners and the observation sheet of the multiple intelligence activities, while the tests was used to measure students's mastery concepts. The results show that naturalistic intelligence has the highest percentage, while the lowest percentage is logical mathematical intelligence. It was also found that using integrated teaching materials of ESS with accommodate multiple intelligences enhanced the students's mastery concepts of the motion of celestial bodies.
\end{abstract}

Keywords-teaching materials; ESS integrated; multiple intelligence; mastery concepts

\section{INTRODUCTION}

Earth and Space Sciences (ESS) is part of an integrated science subjects in secondary school. Based on the results of interviews conducted by Budianto (2015) to some teachers indicated that 3 out of 5 teachers argue that one of the factors inhibiting the implementation of learning ESS is ESS range of material on teaching materials it limited and elusive [1]. In addition, from the results of interviews with one of science teachers stated that the content of ESS teaching materials commonly used only limited knowledge not understandable. It supported by the results of material concept the test of ESS by theme of "Motion Sky Objects" to the ninth class students of Junior High School in Bandung, it showed unsatisfactory results. The average score no more than 50 with range of score 1-100 (Budianto). The Low of students' understanding of ESS material happened because students learn by lecture and memorize, so for students who do not like the method can be a barrier for sharpening the intellegence [2].

Intelligence is one of the main factors that determine the success of student learning. The result of the preliminary identification showed that students have diverse intellectual. It effects to the students' understanding in catching the concept given. The availability of an appropriate teaching material that can optimize all the intelligence of students may facilitate students mastery concepts.

There are many teaching materials used and utilized in Earth and Space Sciences (ESS) learning, one of teaching materials in Earth and Space Sciences (ESS) integrated by theme the motion of celestial bodies which oriented to accommodate multiple intelligence that written by Toto. Budianto. This book integrated teaching materials in Earth and Space Sciences (ESS) with other subjects. The subjects are physics, geography, mathematics, and religion. The book also accommodates multiple intelligences in each phase of learning. This is very important because the assessment and 
learning outcomes without accommodating all the intelligence is a form of deprivation or inhibition of intelligence of students.

Integrated teaching materials of ESS with accommodate multiple intelligences written by Toto Budianto, et al. It considering the diversity of students' intelligence that will help students in obtaining information regarding the material of ESS and optimizes the various intelligence of students, especially to increase students' mastery concept. According to Howard Gardner (1983), intelligence is an ability to solve problems and create products that have culture value. He also mentioned that each individual has eight types of intelligence called multiple intelligences, including linguistic, logicalmathematical, visual-spatial, body-kinesthetic, musical, interpersonal, intrapersonal, and naturalist [3].

The teaching material written by Toto Budiono, et al, is a teaching material in which teaching materials of ESS associating theme with several subjects including Physics, Geography, Religion and Math as well as accommodate eight multiple intelligences. It consists of six sub themes, namely he motion of celestial bodies, the laws of Kepler, phases of the moon, eclipses, events rotation and revolution of the Earth, and artificial satellites. Based on consideration of the study period, it only three sub themes that used in learning. After adjusting with Competency Standards (CK) and the Basic Competency (BC) on several subjects, this study uses only three sub themes. The first sub theme is the motion of celestial bodies, the second sub theme is the laws of Kepler, and the theme of the third sub-themes is the eclipse. All The syllabus, lesson plans and instructional media suitable to the material and activities that have been specified in instructional materials.

Subtheme motion of celestial bodies is done in one meeting. It consists of the material rotational motion and the motion of the revolution, the rotation period and the period of revolution of the Earth, facts Earth rotates wisdom rotation period that owned the Earth, the wisdom of day and night, and the wisdom of the value of the Earth against the sun. Kepler's laws subtheme consisted of two meetings, the second and third meetings consisting of material legal proof 1 Kepler, The second of Kepler's law of evidence, proof of the third Kepler's law, Newton's law of gravity, the law of conservation of mechanical energy, the law of conservation of angular momentum, and the model Nebula. Subtheme eclipse consisted of one meeting consisting of the material shadow umbra and penumbra, polychromatic light, light dispersion, and the guidance of Islamic law when an eclipse happened.

In the teaching materials, discussion of the material in each sub-theme is designed to accommodate the intelligence of the students. Based on these targets, the teaching material used the form of review materials, teaching materials Earth and Space Sciences (ESS) Toto Budianto, et al. equipped with a wide range of student activities. Table 1 shown in details of the activities in each sub-theme.
TABLE I. SUBTHEME ACTIVITIES MATERIAL MOTION OF CELESTIAL BODIES

\begin{tabular}{|l|l|}
\hline \multicolumn{1}{|c|}{ Intelligences } & \multicolumn{1}{c|}{ Activity } \\
\hline Naturalist & $\begin{array}{l}\text { Explanations of natural phenomena related } \\
\text { to the motion of celestial bodies }\end{array}$ \\
\hline Linguistic & $\begin{array}{l}\text { Writing down about the apparent daily } \\
\text { motion of the Sun }\end{array}$ \\
\hline logical-mathematical & $\begin{array}{l}\text { Make a list of planets based on the period } \\
\text { of rotation and revolution }\end{array}$ \\
\hline visual-spatial & $\begin{array}{l}\text { Drawing deflection of the wind direction } \\
\text { on the globe }\end{array}$ \\
\hline body-kinesthetic & $\begin{array}{l}\text { Activity Being Scientist 1.1 and Being } \\
\text { Scientist 1.2 }\end{array}$ \\
\hline Interpersonal & Group discussion \\
\hline Intrapersonal & Give reflection sheet \\
\hline
\end{tabular}

Activity Being Scientist 1.1 and Being Scientist 1.2 is a radiant experimental activity to prove the rotation of the Earth as the cause of day and night phenomenon.

\section{TABLE II. SUBTHEME ACTIVITIES KEPLER LAWS}

\begin{tabular}{|l|l|}
\hline \multicolumn{1}{|c|}{ Intelligences } & \multicolumn{1}{c|}{ Activity } \\
\hline Linguistic & $\begin{array}{l}\text { Playing a role in the story of Newton and the } \\
\text { apple }\end{array}$ \\
\hline logical-mathematical & Prove Kepler laws \\
\hline visual-spatial & Drawing trajectory planet \\
\hline body-kinesthetic & Activity I Can 2.1 and I Can 2.2 \\
\hline Interpersonal & Group discussion \\
\hline Naturalist & $\begin{array}{l}\text { Explanations of natural phenomena related to } \\
\text { Kepler's laws }\end{array}$ \\
\hline Intrapersonal & Give reflection sheet \\
\hline
\end{tabular}

Activity I Can 2.1 is the activity of an experiment to prove the applicability of the law of conservation of energy. Activity I Can 2.2 Experiment to prove Kepler's laws

TABLE III. SUBTHEME ACTIVITY ECLIPSE

\begin{tabular}{|l|l|}
\hline Intelligences & Activity \\
\hline Musical & Sing the song about eclipse \\
\hline visual-spatial & $\begin{array}{l}\text { Draw a sketch of the occurrence of the } \\
\text { eclipse }\end{array}$ \\
\hline body-kinesthetic & $\begin{array}{l}\text { Event experiments identify shadow of umbra } \\
\text { and penumbra }\end{array}$ \\
\hline Interpersonal & Group discussion \\
\hline Naturalist & $\begin{array}{l}\text { Explanations of natural phenomena } \\
\text { associated eclipse }\end{array}$ \\
\hline Intrapersonal & Give reflection sheet \\
\hline
\end{tabular}




\section{A. Concept Mastery Test}

Dahar (1989) defines the concept as the foundation stones of thinking obtained through the facts and can be used to solve the problem. [4]

As for the definition of a more comprehensive mastery of concepts proposed by Bloom ( Rustaman et al., 2005) which is the ability to capture notions like being able to disclose a material that is presented in more understandable form, is able to provide interpretation and able to apply [5].

\section{METHOD}

\section{A. Research Design}

In this study, researchers provided treatment in the form of learning using integrated teaching materials of ESS with accommodate multiple intelligences to know the profile of the multiple intelligences of students and gain an overview of improving student learning outcomes. The study design used Pre Experimental design or Quasi-Experimental with one shoot pre-test and post-test group [6].

The Pattern one shoot pre-test and post-test group as follows:

$$
\begin{array}{lll}
\mathbf{0}_{1} & \mathbf{X} & \mathbf{0}_{2}
\end{array}
$$

Fig.1. Pattern One Shoot Pre-Test and Post-Test Group

In this design the observation did twice: before learning with integrated teaching materials of ESS with accommodate multiple intelligences and after learning with integrated teaching materials of ESS with accommodate multiple intelligences. Observations made before learning using integrated teaching materials of ESS with accommodate multiple intelligences (01) called a pre-test, and observation after learning using integrated teaching materials of ESS with accommodate multiple intelligences (02) called a post-test. Learning to integrated teaching materials of ESS with accommodate multiple intelligences called a treatment $(\mathrm{X})$.

\section{B. Participants}

The subjects in this study is students of ninth class of Junior High School 32 students. Subjects observed during the learning activities using integrated teaching materials of ESS with accommodate multiple intelligences during four meetings. Place of research conducted in Nurul Amanah Islamic Integrated Junior High School Tasikmalaya.

\section{Research Instruments}

The instrument that used in this research consist of questionnaires, observation sheets, and test.

\section{1) Multiple Intelligences Quistionnaire}

Multiple intelligences questionnaire used to identify multiple intelligences' students of ninth class of Junior High
School. The questionnaire consisted of 40 statements which contains the scope of multiple intelligences.

2) Observation Sheet of Multiple Intelligences Activity

Observation sheet of multiple intelligences created in three forms namely self assessment, peer assessment, and observation assessment. This observation contain the related statements about multiple intelligences activity which aim to know the appeared of students multiple intelligences activity.

\section{3) Concept Mastery Test}

The tests about mastery concepts presented in narrative form. Implementation of the pretest and posttest performed for each subtheme. The test questions of mastery concept motion of celestial bodies composed of 11 questions, sub themes Kepler's laws consists of six questions, sub themes eclipse consists of 8 questions.

\section{Data Analysis}

1) Multiple Intelligences Questionnaire

Multiple intelligence questionnaire consist of 40 statements that represent the multiple intelligences' students. Each statement was assessed using a Likert scale with a rating scale of 0-4. Each multiple intelligence consists of five statements are arranged randomly. Then the assessment scores added for each of multiple intelligences. If obtained the highest total score in one or more of the multiple intelligences, then these students have the dominant intelligence.

\section{2) Observation Sheet of Multiple Intelligences Activity}

Observation sheets of multiple intelligence activity assessed by assessing the enforceability of any activity that accommodates multiple intelligences of students. Scores for each activity is $0-1$. Score of 0 indicates that accommodates an intelligence activity does not appear / not carried out by students, while a score of 1 indicates an activity that accommodates multiple intelligences raised / implemented by the students.

\section{3) Concept Mastery Test}

Tests of the mastery of concepts analyzed using N-gain. Ngain calculation is done to see an increase in students' mastery of concepts on the theme of motion of celestial bodies with learning using teaching materials ESS integrated accommodate multiple intelligences. Score criteria for the Ngain is shown in Table 4 [7].

TABLE IV. SCORE CRITERIA $N$-GAIN

\begin{tabular}{|c|c|}
\hline$\langle\mathbf{g}\rangle$ & Category \\
\hline$g \geq 0,7$ & High \\
\hline $0,3 \leq g \leq 0,7$ & Middle \\
\hline$g \leq 0,3$ & Low \\
\hline
\end{tabular}

III. RESULTS AND DISCUSSION

\section{A. Identification of Multiple Intelligences}

The identification of multiple intelligences of students conducted by questionnaire test of multiple intelligences in 
junior high school in Tasikmalaya district, The number of students who completed questionnaires 32 students with the details of 18 female students and 14 male students. The result multiple intelligences of students are shown in Figure 2.

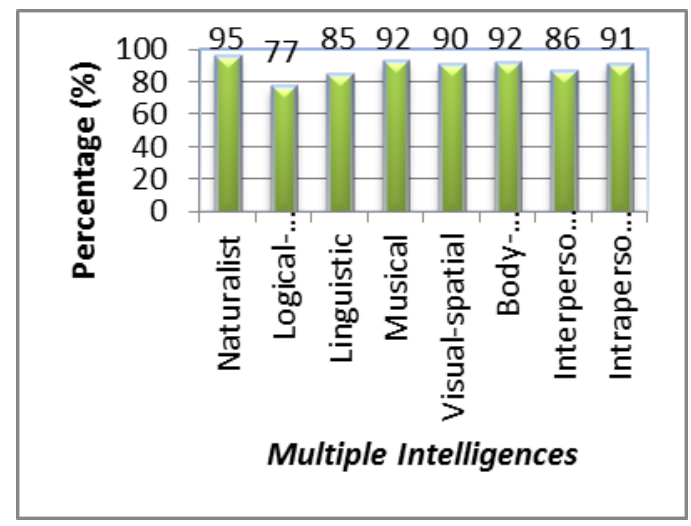

Fig.2. The percentage of students' dominant multiple intelligences

The majority of students in classroom research have kinesthetic intelligence $31 \%$. As for logical mathematical intelligence there was no student dominated

\section{B. Profile of Students' Multiple Intelligences Activities}

After conducting learning using teaching materials ESS integrated accommodate multiple intelligences, it was obtained the observation of multiple intelligences the process activity of students. Based on the overall assessment using three instruments, the average percentage of student activity that gave rise to the multiple intelligences is presented in Figure 3.

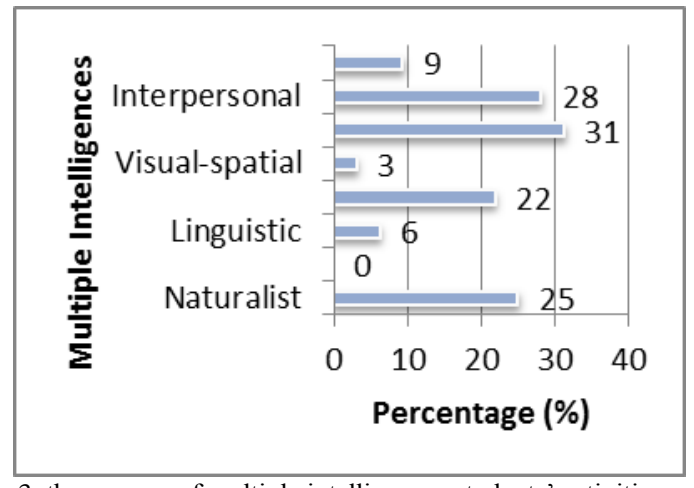

Fig.3. the process of multiple intelligences students' activities

Based on the assessment using the three instruments, it can be seen that the emergence of multiple intelligence activity with the highest percentage, naturalistic intelligence $95 \%$, while the emergence of multiple intelligence activity with the lowest percentage of logical mathematical intelligence $77 \%$. The process of multiple intelligence activity with the lowest percentage in accordance with the results of multiple intelligence questionnaire dominant that distributed. The questionnaire results showed the percentage of multiple intelligences of students for logical mathematical intelligence is $0 \%$. On learning activities can be seen that the students looked confused and less enthusiastic when doing activities that contain elements of logical mathematical intelligence, it took more time to do the activities. In addition teachers guided students more seriously when doing activities related to mathematical logic. This is also in line with studies conducted by Xie and Lin (2009) concerning the teaching and assessment of multiple intelligences. They mentioned that students in the experimental class are weak in verbal intelligence logical mathematical and linguistics [8].

C. Correlation Between Dominant Multiple Intelligences with Appeared of Multiple Intelligences Activities

If the assessment of multiple intelligences activity associated with students' dominant multiple intelligences, then the result can be seen in Table V.

TABLE V. CORRELATION BETWEEN DOMINANT MULTIPLE INTELLIGENCES AND ACTIVITIES THAT APPEAR MULTIPLE INTELLIGENCES

\begin{tabular}{|c|c|c|c|c|c|c|c|c|}
\hline \multirow[b]{2}{*}{$\begin{array}{l}\text { Dominant } \\
\text { Intelligences }\end{array}$} & \multicolumn{8}{|c|}{ Multiple Intelligences Activity } \\
\hline & 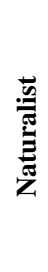 & 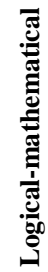 & & 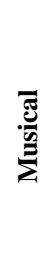 & 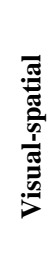 & 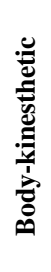 & 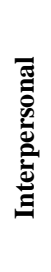 & 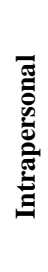 \\
\hline Naturalist & 98 & 86 & 96 & 100 & 92 & 92 & 90 & 97 \\
\hline $\begin{array}{c}\text { Logical- } \\
\text { mathematical }\end{array}$ & - & - & - & - & - & - & - & - \\
\hline Linguistic & 100 & 92 & 94 & 100 & 100 & 100 & 90 & 100 \\
\hline Musical & 95 & 73 & 78 & 90 & 94 & 88 & 81 & 90 \\
\hline Visual-spatial & 100 & 83 & 89 & 100 & 100 & 100 & 81 & 100 \\
\hline $\begin{array}{c}\text { Body- } \\
\text { kinesthetic }\end{array}$ & 90 & 75 & 79 & 73 & 83 & 95 & 86 & 88 \\
\hline Interpersonal & 94 & 69 & 88 & 96 & 95 & 87 & 91 & 95 \\
\hline Intrapersonal & 94 & 72 & 89 & 89 & 96 & 89 & 86 & 98 \\
\hline
\end{tabular}

Note: The blue column indicates the highest percentage of the multiple intelligences activity.

Based on Table V. it is shown that there is a pattern match between the dominant intelligence of students with the appeared of multiple intelligences activities of students during learning. As the appeared of visual-spatial intelligence, kinesthetic intelligence, and intrapersonal intelligence have the correlation with its dominant intelligences. But there were multiple intelligences activities that have no correlation with its dominant intelligences. It is like, naturalistic intelligence, linguistic, musical, interpersonal. 
The percentages of students' dominant intelligences that have correlation activities that appear multiple intelligences were for $69 \%$. Meanwhile, percentage of student dominant intelligences that have no correlation with student activity that appear multiple intelligences was for $31 \%$. The discrepancy between students' dominant intelligences and activities that appear multiple intelligences during the learning occurred, because it was not develop totally. The materials and activities available on teaching materials with the optimal learning designed in lesson plan less attractive and less enthusiastic students to follow. Dominant verbal linguistic intelligence have no correlation because activities designed such as playing the character and dialogue, so students can get a dialogue partner unsuitable, students got lack the spirit of dialogue. Interpersonal intelligence has no correlation because students are not suited to the group of their friends so that students are not able to work well together in completing the task. This is consistent with studies conducted by Xie and Lin (2009) which states that compared to traditional learning, multiple intelligences learning students need more time and preparation [9] . So, the teacher must prepare learning with more leverage.

In addition, dominant intelligences that has no correlation with multiple intelligences activity can also be due to of teachers with in less precise so students are less able to understand the material or direction given. This is consistent with the research conducted by Griggs et al. (2009) about the variation in learning to direct the multiple intelligences of students. The results showed that students in each class showed a particularly strong intelligence that is not aligned with the instructional lecture or notes. It shows teachers must change the way they teach that coinciding with students' condition [10].

\section{Concept Mastery Test}

The Tests of concept mastery consists of pretest and posttest. Material provided by the teacher consists of three sub-themes, so that tests mastery of the concept of each subtheme. Problem test is a matter of description. Increasing students' mastery of concepts is measured by the average gain is normalized (N-gain) from the score pretest and posttest. The research obtained that the average score for overall pretest material is 19.4 and the average of the posttest for the overall material is 59.6 on a scale of 100 . Then $\mathrm{N}$-gain value obtained is 0.5 which is included into the category of middle.

The acquisition value of N-Gain on each of the sub-theme shows that the $\mathrm{N}$-gain of motion of celestial bodies is 0.3 and included into the lower category. As for the theme of Kepler's laws and values eclipse 0.6 and included into the category of middle. The mastery of concepts Increased for a subtheme of motion of celestial bodies included into the category of low, this could be due to the learning that is designed by a teacher lacking attract the attention of students so that students are less enthusiastic in participating in learning. In addition, other causes, the explanation gave by the teacher not understood by students.
To sub theme Kepler's laws, the average score of the NGain in middle category. In sub theme Kepler's laws, The increasing of students' mastery concepts quite visible. It is caused when the pretest, nearly all the students could not answer the question about the laws of Kepler Many students said she had never heard of Kepler's laws. Because Kepler's laws are still unfamiliar, in the lprocess of learning, students are enthusiastic because it has a high curiosity about the material. In addition, the study designed by teachers for Kepler's laws sub-theme attracts enough students. Learning designed teachers consists of drawing, playing games, role playing, even there are activities that use the laptop as a medium.

For sub theme eclipse, the average value of the N-Gain students in middle category. Increased procurement sub theme eclipse concept is quite visible, it is because students are quite excited when they hear this matter, the students' interesting saw since the students began to make observations from a video.

\section{Conclusion}

The results of the study concludes that the teaching materials Earth and Space Sciences (ESS) integrated accommodate multiple intelligences can be used as an alternative to classroom learning with the development from teachers in the preparation of syllabus, lesson plans, and exciting learning media in order to optimize the various intelligence of students.

\section{Acknowledgment}

Researchers would like to thank the Department of Physical Education for supporting the research.

\section{References}

[1] Budianto, T. (2015). Penyusunan Bahan Ajar Ilmu Pengetahuan Bumi dan Antariksa (IPBA) Terintegrasi Tema Gerak Benda Langit Berorientasi Pengakomodasian Kecerdasan Mejemuk dan Penanaman Karakter Siswa SMP (Essay). Indonesian education university. Bandung.

[2] Luthfiani, T.A. (2015). Analisis Karakter Diri dan Kecerdasan Majemuk Siswa Sekolah Dasar pada Model Pembelajaran IPA Terpadu yang Mengakomdasi Kecerdasan Majemuk.. (Essay). Indonesian education university. Bandung.

[3] Gardner, H. (1983; 1993). Frames of Mind: The Theory of Multiple Intelligences, Newyork: Basic Book.

[4] Dahar, R. W. (2003). Teori-Teori Belajar dan Pembelajaran. Jakarta: Erlangga.

[5] Rustaman, N. Y. (2005). Pengembangan Konsep. Bandung: Remaja Rosdakarya.

[6] Hake, R. (1998). "Interactive-engagement versus traditional methods: a six-thousand-student survey of mechanics test data for introductory physics courses". Am J Phys, 66(1), 64-67 
[7] Arikunto, S. (2010). Prosedur Penelitian: Suatu Pendekatan Praktik. Jakarta: Rineka Cipta

[8] Xie, J.C. \& Lin, R.L. (2009). Research on multiple intelligences teaching and assessment. Asian Journal of Management and Humanity Sciences. 4 (2-3) .hlm 106124.

[9] Xie, J.C. \& Lin, R.L. (2009). Research on multiple intelligences teaching and assessment. Asian Journal of
Management and Humanity Sciences. 4 (2-3), pp 106124.

[10] Griggs. K. Barney, S., Sederberg. J.B., Collins, E., \& Keith, S. (2009). Varying pedagogy to address student's multiple intelligences. Human Architecture: Journal of the Sociology of Self-Knowledge. 7 (1), p. 55-6 